Ireneusz S. Grat

\title{
Uchwalenie dekretu z 22 stycznia 1946 r. o wyjątkowym dopuszczeniu do obejmowania stanowisk sędziowskich, prokuratorskich i notarialnych oraz do wpisania na listę adwokatów
}

Keywords: Legal professions

\section{Summary}

When communists took power in Poland in 1944, they had not enough qualified lawyers to control the judiciary system and the prosecutor's office. They were forced to employ lawyers educated before the war, in different political situation. These lawyers were in opposition to new authority. Because of these reasons the decree of 22 January 1946 was passed. According to it, the Minister of Justice could appoint for judge, prosecutor, attorney and notary any person, even not having legal education. The decree can be regarded as a specific punishment for independent lawyers. The decree established quick and short way to obtain legal profession for those, who were supporting new communist rule. It caused that the judges stopped being independent.

Obejmując władzę w Polsce, komuniści nie posiadali dostatecznej liczby wykształconych i zaufanych osób, którymi mogliby obsadzić państwowe instytucje, w tym budowany przez siebie aparat wymiaru sprawiedliwości ${ }^{1}$. Przy obsadza-

${ }^{1}$ Leon Chajn opisując okoliczności objęcia przez siebie stanowiska wiceministra sprawiedliwości wspomina, że zaoponował, gdy Edward Osóbka-Morawski zaproponował mu stanowisko wiceministra sprawiedliwości. Odmawiając, tłumaczył się brakiem doświadczenia. E. Osóbka-Morawski oświadczył wówczas, że sam także nie uczył się kierować państwem, gdy był instruktorem w spółdzielni oraz administratorem w WSM-ie. A najwyższa funkcja, jaką do tej pory pełnił, to była posada dyrektora Gospody Spółdzielczej. L. Chajn, Kiedy Lublin był Warszawą, Warszawa 1964, s. 19. 
niu sądów i prokuratur musieli się opierać na przedwojennej kadrze sędziowskiej i prokuratorskiej. Stanowiła ona zdecydowaną większość zatrudnionych w wymiarze sprawiedliwości².

Zwolennikiem odbudowy wymiaru sprawiedliwości opartego na przedwojennej kadrze był m.in. przewodniczący PKWN Edward Osóbka-Morawski, który uważał, że należy zatrudnić każdego przedwojennego sędziego i prokuratora, jeśli tylko zechce „lojalnie współpracować z władzą ludową”3. Braki kadrowe w sądownictwie i prokuraturze były tak duże, że utworzono nawet specjalne grupy operacyjne. Ich zadanie polegało na organizowaniu zebrań, na których proponowano pracę osobom wcześniej zatrudnionym w przedwojennym wymiarze sprawiedliwości ${ }^{4}$.

Przyjmując do pracy przedwojenne kadry prawne, komuniści nie wymagali od nich czynnego zaangażowania w umacnianiu nowej władzy, wystarczała im deklaracja lojalności ${ }^{5}$. Szybko jednak zaczęto na nich naciskać, szantażując, że jeśli nie zajmą „zdecydowanego stanowiska w interesie żywotnych spraw narodowych - to Demokracja Polska zmuszona będzie sięgnąć po nowe formy sądownictwa kosztem zrezygnowania z kultu fachowości sądownictwa polskiego"6.

Nową władzę od początku nurtowało pytanie, czy słuszne było przywrócenie do pracy starych kadr sędziowsko-prokuratorskich?? Zatrudnienie wykształconych przed wojną prawników niosło bowiem ze sobą niebezpieczeństwo wydawania wyroków sprzecznych z wolą nowej władzy.

Tak też było w istocie. Przedwojennym prawnikom zarzucano, że ich myślenie obarczone jest balastem fałszywych i szkodliwych poglądów na rolę magistratury sądowej oraz rutyną i nawykami praktyki burżuazyjnego sądownictwa, że bazując na abstrakcyjnej sprawiedliwości oddzielają się murem od „rewolucyjnych przemian zachodzących w Polsce Ludowej”8 oraz że nie stoją na straży rewolucyjnej praworządności.

2 Adam Lityński podaje, że pod koniec 1946 r. budowany przez komunistów aparat wymiaru sprawiedliwości w $90 \%$ opierał się na przedwojennych sędziach i prokuratorach. A. Lityński, O prawie i sądach początków Polski Ludowej, Białystok 1999, s. 130-131.

${ }^{3}$ L. Chajn, Kiedy Lublin był Warszawa..., s. 20.

4 Jedno z takich zebrań zorganizowane zostało 17 stycznia 1945 r. w Kielcach. Przybyli na nie sędziowie, prokuratorzy, adwokaci, notariusze, urzędnicy i woźni sądowi. Nieoczekiwanie zjawili się na nim również żołnierze radzieccy, którzy po wylegitymowaniu obecnych aresztowali sędziów i prokuratorów, a następnie wywieźli ich w nieznanym kierunku. Próby uwolnienia zatrzymanych podją się L. Chajn, jednakże dopiero telefoniczna interwencja B. Bieruta u J. Stalina przywróciła wolność polskim sędziom i prokuratorom. Następnego dnia historia powtórzyła się z sędziami i prokuratorami, którzy stawili się na zebranie informacyjne zorganizowane w Radomiu. Ibidem, s. 78 i n.

${ }^{5}$ Przemówienie ministra sprawiedliwości Henryka Świątkowskiego podsumowujące Krajową Naradę Aktywu Sądowo-Prokuratorskiego, która odbyła się 24 czerwca 1949 r. w Ministerstwie Sprawiedliwości. Z Krajowej Narady Aktywu Sądowo-Prokuratorskiego, „Demokratyczny Przegląd Prawniczy” (dalej: DPP) 1949, nr 6-7, s. 94.

${ }^{6}$ L. Chajn, Kiedy Lublin był Warszawą..., s. 45.

Ibidem, s. 42.

8 Z. Kliszko, W pięciolecie wymiaru sprawiedliwości, DPP 1948, nr 6-7, s. 3. 
Podobne zarzuty kierowane były pod adresem ferowanych przez nich wyroków; wyrokom tym zarzucano łagodność, przejawiającą się w zbyt częstym orzekaniu warunkowego zawieszenia wykonania kary. Komuniści uważali, że tak można było skazywać przed wojną, ale obecnie taki wyrok jest swego rodzaju przestępstwem ${ }^{9}$. Wydawane w sądach doraźnych wyroki skazujące na karę w zawieszeniu uznawali za wrogie działania, wymierzone przeciwko nowej władzy. Jak to ujął Stefan Bancerz - dyrektor Departamentu Ustawodawczego w Ministerstwie Sprawiedliwości - sędziowie, którzy ferują takie wyroki, sami na siebie wydali wyrok i należy ich wydalić z sądownictwa ${ }^{10}$. Podobne stanowisko zajmował sekretarz generalny KC PPR W. Gomułka. Domagał się systematycznego oczyszczania aparatu wymiaru sprawiedliwości z ludzi, którzy przed wojną „przejawiali nadmierną gorliwość w realizowaniu sanacyjnej polityki”"11 i zastępowania ich nowymi, młodymi sędziami i prokuratorami ${ }^{12}$.

W celu uzyskania pełnej kontroli nad orzecznictwem postanowiono usuwać niewygodnych sędziów. Spełniła się groźba wypowiedziana przez L. Chajna. Komuniści sięgnęli po "nowe formy sądownictwa” ${ }^{13}$. Uznali, że nie może być w Polsce sędzią osoba, która ma negatywny stosunek do nowego ustroju ${ }^{14}$. Nowego prawa nie może bowiem stosować ten, kto nie rozumie i nie odczuwa dokonanego w Polsce przewrotu ${ }^{15}$. Jednocześnie, z uwagi na brak dostatecznej liczby doświadczonych pracowników wymiaru sprawiedliwości, postanowiono utworzyć szybką ścieżkę awansu i zasilić kadry sądownictwa i prokuratury wiernymi, zaufanymi ludźmi spośród chłopów i robotników ${ }^{16}$.

Nowy sędzia i nowy prokurator mieli umożliwić stworzenie nowego modelu sądownictwa, w którym sąd i prokuratura stałyby na straży nowego ustroju ${ }^{17}$,

9 L. Chajn, Trzeci rok, DPP 1946, nr 7, s. 7.

10 S. Bancerz, Wymiar sprawiedliwości w świetle narady krajowej prawników PPR, DPP 1946, nr 9-10, s. 30 .

${ }^{11}$ L. Chajn, Kiedy Lublin byt Warszawą..., s. 43.

${ }^{12}$ Podobne stanowisko znaleźć można we wspomnieniach Wacława Barcikowskiego - ówczesnego I Prezesa Sądu Najwyższego: „Rozumiałem, że należało usunąć z sądów ludzi związanych z poprzednim systemem, a wrogo ustosunkowanych do nowej władzy. Ale przy tak uszczuplonych kadrach sądowniczych należało korzystać ze zdolności lojalnych przedwojennych sędziów, choćby dlatego, że brakowało innych. [...] Pocieszałem się, że z czasem zastąpią ją [tj. przedwojenną kadrę - I.S.G.] zupełnie nowi ludzie - robotnicy z pochodzenia, o zdrowym rozsądku i zdrowych pojęciach na temat wymiaru sprawiedliwości”. W. Barcikowski, W kręgu prawa i polityki. Wspomnienia z lat 1919-1956, Katowice 1988, s. $152-153$.

${ }^{13}$ L. Chajn, Kiedy Lublin był Warszawą..., s. 45.

${ }^{14}$ L. Chajn, O właściwe rozeznanie. Na marginesie trzeciej rocznicy manifestu PKWN, DPP 1947, nr 7, s. 5 .

${ }^{15}$ L. Chajn, Administracja i sądownictwo w służbie praworządności, DPP 1946, nr 8, s. 5.

${ }^{16}$ Demokratyzacja aparatu państwowego, „Głos Ludu” z 24 października 1945 r. L. Chajn, Na progu wielkiej reformy, DPP 1947, nr 4, s. 8.

17 Przemówienie H. Świątkowskiego, wygłoszone na zakończenie pierwszego kursu prokuratorskiego Szkoły Prawniczej w Łodzi. Zakończenie I-go kursu prokuratorskiego Szkoły Prawniczej w Łodzi. 37 nowych prokuratorów, DPP 1946, nr 11-12, s. 72. 
byłyby instrumentami klasowego panowania ${ }^{18}$. Szybką ścieżkę awansu dla zaufanych ludzi zapewniał uchwalony w styczniu 1946 r. dekret o wyjątkowym dopuszczeniu do obejmowania stanowisk sędziowskich, prokuratorskich i notarialnych oraz do wpisania na listę adwokatów ${ }^{19}$. Dekret zezwalał ministrowi sprawiedliwości na nominacje sędziowskie, prokuratorskie i notariackie osób, które nie posiadały prawniczego wykształcenia na poziomie uniwersyteckim. Minister sprawiedliwości mógł zwolnić z obowiązku odbycia odpowiedniej aplikacji osoby ubiegające się o stanowiska sędziowskie, notariackie ${ }^{20}$ lub adwokackie. Od kandydatów do stanowisk sędziowskich oraz prokuratorskich i adwokackich wymagano, by dawali rękojmię należytego wykonywania zawodu ${ }^{21}$. Spośród wymienionych zawodów jedynie w przypadku adwokatów wymagano, by ukończyli studia prawnicze na poziomie uniwersyteckim (art. 3 ust. 1).

Jednakże postanowienia dekretu nie są w tym zakresie konsekwentne. Zgodnie $\mathrm{z}$ art. 3 ust. 2 na listę adwokatów mogły być również wpisane osoby, które nie ukończyły studiów prawniczych. Dekret dawał taką możliwość obrońcom sądowym i obrońcom przy sądach grodzkich, którzy na mocy dekretu z 8 lutego 1919 r. w przedmiocie przepisów tymczasowych o obrońcach sądowych i obrońcach [przy sądach] ${ }^{22}$ pokoju upoważnieni zostali do prowadzenia cudzych spraw (art. 3 ust. 2$)^{23}$.

Zgodnie $\mathrm{z}$ dekretem o wyjątkowym dopuszczeniu do obejmowania stanowisk sędziowskich, prokuratorskich i notarialnych oraz do wpisania na listę adwokatów kandydaci na sędziów i prokuratorów powinni wykazać się kwalifikacjami osobistymi oraz działalnością naukową, zawodową, społeczną lub polityczną, a także dostateczną znajomością prawa, nabytą w pracy zawodowej lub uznanych przez ministra sprawiedliwości szkołach prawniczych (art. 1 ust. 1). W przypadku notariuszy, wymagano by kandydat miał przynajmniej dziesięcio-

${ }^{18}$ Przemówienie H. Świątkowskiego, wygłoszone 24 czerwca 1949 r. na Krajowej Naradzie Aktywu Sądowo-Prokuratorskiego. Z Krajowej Narady Aktywu Sąowo-Prokuratorskiego, op. cit., s. 87.

${ }^{19}$ Dz.U. Nr 4, poz. 33.

${ }^{20}$ Więcej na temat notariatu w początkach Polski Ludowej: Dorota Malec, Dzieje notariatu polskiego, Kraków 2007.

${ }^{21}$ Marcin Zaborski zwraca uwagę, że dekret ten jest pierwszym aktem prawnym, który wprowadza pojęcie rękojmi należytego wykonywania zawodu. M. Zaborski, Szkolenie „sędziów nowego typu” w Polsce Ludowej. „Palestra” 1998, nr 1-2, s. 80.

${ }^{22} \mathrm{~W}$ ustępie tym przywołano błędną nazwę dekretu z 8 lutego 1919 r. Prawidłowa nazwa brzmi: dekret w przedmiocie przepisów tymczasowych o obrońcach sądowych i obrońcach przy sądach pokoju.

${ }^{23}$ „Obrońcy sądowi i obrońcy przy sądach grodzkich, upoważnieni do prowadzenia cudzych spraw na mocy dekretu z dnia 8 lutego 1919 r. w przedmiocie przepisów tymczasowych o obrońcach sądowych i obrońcach pokoju (Dz.P.P.P. Nr 15, poz. 205), mogą być wpisani na listę adwokatów zgodnie z ust. 1, chociażby nie ukończyli studiów prawniczych z przepisanymi w Polsce egzaminami” (art. 3. ust. 3). Zgodnie z art. 3 dekretu z 8 lutego 1919 r. w przedmiocie przepisów tymczasowych o obrońcach sądowych i obrońcach przy sądach pokoju, obrońcą przy sądach pokoju mogła zostać osoba, która skończyła 25 lat, biegle włada językiem polskim w mowie i piśmie, ukończyła 4 klasy szkoły średniej oraz zdała przy właściwym sądzie egzamin ze znajomości prawa. Dz.P.P.P. Nr 15, poz. 205. 
letnią praktykę urzędniczą w kancelarii hipotecznej lub notarialnej oraz posiadał odpowiednie kwalifikacje osobiste i dostateczną znajomość prawa (art. 2 ust. 1).

Projekt dekretu przygotowano w Ministerstwie Sprawiedliwości. Jego pierwotna wersja zakładała, że „osoby, które przesłużyły w charakterze sekretarzy i urzędników kancelaryjnych w sekretariatach sądowych lub prokuratorskich albo na stanowisku pisarza hipotecznego lub urzędnika kancelarii hipotecznej lub notarialnej nie mniej niż lat ${ }^{24}$ i posiadają odpowiednie kwalifikacje osobiste oraz dostateczną znajomość prawa mogą być mianowani na stanowisko asesora sądowego, sędziego lub prokuratora, po udzieleniu im zwolnienia od wymagań ukończenia uniwersyteckich studiów prawniczych z przepisanymi w Polsce egzaminami, odbycia aplikacji sądowej i złożenia egzaminu sędziowskiego" (art. 1. ust. 1) ${ }^{25}$.

Postanowienia tego projektu zakładały, że przepisy ust. 1 należy stosować odpowiednio do absolwentów uniwersyteckich studiów prawniczych, jeśli ich działalność naukowa ewentualnie zawodowa daje rękojmię należytego wykonywania obowiązków sędziowskich lub prokuratorskich. Nie musieliby oni odbywać aplikacji sądowej ani zdawać egzaminów sędziowskich. Zakładano, że zwolnień oraz zezwoleń, o których mowa w dekrecie, będzie przez trzy lata od wejścia w życie dekretu udzielał minister sprawiedliwości (art. 4 projektu dekretu).

Projekt ten zawierał również postanowienia, które w całości zostały powtórzone w ostatecznej wersji dekretu. Dotyczy to art. 1 ust. 2, art. 2 ust. 2, art. 3 ust. 1 , art. 5 oraz art. 6 . Artykuł 3 ust. 2 projektu w ostatecznej wersji dekretu został umieszczony jako art. 3 ust. 3, gdyż nowy ustęp 2 tego artykułu uwzględniał postulaty Zrzeszenia Obrońców Sądowych Rzeczypospolitej Polskiej. Domagano się w nich zrównania obrońców sądowych i obrońców przy sądach grodzkich $\mathrm{z}$ uprawnieniami adwokatów ${ }^{26}$. Artykuł 2 ust. 1 projektu jest niemal identyczny $\mathrm{z}$ wersją ostateczną dekretu. W projekcie zostawiono puste miejsce, w które $\mathrm{w}$ późniejszym czasie wpisano cyfrę $10^{27}$, oznaczającą liczbę lat pracy w charakterze urzędnika w kancelarii hipotecznej lub notarialnej, jaka jest wymagana w celu uzyskania mianowania na stanowisko notariusza.

${ }^{24} \mathrm{~W}$ projekcie pozostawiono puste miejsce. W trakcie późniejszych prac wpisano $\mathrm{w}$ nie cyfrę "10".

${ }^{25}$ Archiwum Akt Nowych Ministerstwo Sprawiedliwości (dalej: AAN MS) 4301, k. 19.

${ }^{26}$ Pismo Zarządu Głównego Zrzeszenia Obrońców Sądowych Rzeczypospolitej Polskiej z 6 XII 1946 r. skierowane do ministra sprawiedliwości. W piśmie tym przywołane są: a) skierowany do ministra sprawiedliwości memoriał z postulatem zrównania obrońców sądowych i obrońców przy sądach grodzkich z uprawnieniami adwokatów; b) odpowiedź ministra sprawiedliwości z 5 XII 1945 r., że postulaty zawarte w memoriale będą uwzględnione w mającym się wkrótce ukazać dekrecie o wyjątkowym dopuszczeniu do obejmowania stanowisk sędziowskich, prokuratorskich i notarialnych oraz do wpisania na listę adwokatów. AAN MS 4301, k. 49.

${ }^{27}$ Wymóg dziesięcioletniej pracy w kancelarii hipotecznej lub notarialnej zawiera projekt dekretu uchwalony na posiedzeniu Komisji Prawniczej, a załączony do pisma nr UR 490/45 podpisanego przez Stefana Bancerza - dyrektora Departamentu Ustawodawczego Ministerstwa Sprawiedliwości. AAN MS 4301, k. 28 i 29. 
W uwagach do powyższego projektu postulowano wykreślenie wymogu odbycia służby $\mathrm{w}$ charakterze sekretarzy i urzędników kancelaryjnych w sekretariatach sądowych lub prokuratorskich jako warunku mianowania na stanowisko asesora sądowego, sędziego lub prokuratora. Postulowano ponadto, by warunkiem dopuszczenia do sądownictwa i prokuratury był - obok działalności naukowej, zawodowej, społecznej lub politycznej - również poziom wykształcenia kandydata. Czynniki te byłyby gwarancją należytego wykonywania obowiązków sędziowskich i prokuratorskich. Jako dodatkowy wymóg stawiany kandydatom na sędziów i prokuratorów proponowano udział w zorganizowanym przez Ministerstwo Sprawiedliwości szkoleniu, które zakończyłoby się egzaminem ${ }^{28}$.

W dokumencie z 21 IX 1945 r. ${ }^{29}$ znajduje się krytyczna opinia dotycząca objęcia przepisami dekretu wyższych instancji w sądownictwie i w prokuraturze. $\mathrm{W}$ dokumencie tym proponowano zastąpienie wyrazów „sędziego lub prokuratora” wyrazami „sędziego grodzkiego, sędziego sądu okręgowego, podprokuratora lub wiceprokuratora sądu okręgowego". Argumentowano, że zasadnicza myśl projektu jest słuszna i usprawiedliwiona koniecznością uzupełnienia braków kadrowych w sądownictwie, budzi jednak zastrzeżenia objęcie postanowieniami dekretu wyższych instancji, tj. Sądu Najwyższego i sądów apelacyjnych. Tę samą uwagę skierowano pod adresem sędziów okręgowych śledczych. Wszyscy oni powinni mieć ukończone studia prawnicze.

W trakcie prac nad projektem gen. bryg. Aleksander Tarnowski - prezes Najwyższego Sądu Wojskowego zaproponował, by przynależne ministrowi sprawiedliwości kompetencje do udzielania zwolnień od obowiązujących wymagań oraz zezwoleń na dopuszczenie do egzaminów przyznać również ministrowi obrony narodowej. A. Tarnowski wysuwał dwa argumenty przemawiające za tym rozwiązaniem. Po pierwsze, w sądownictwie wojskowym odczuwalny był brak „fachowych sił”, które prowadziły postępowania sądowe i prokuratorskie. Po drugie, przyznanie ministrowi obrony narodowej takich samych uprawnień, jakie $\mathrm{w}$ tej dziedzinie przyznano ministrowi sprawiedliwości, wiązałoby się z demokratyzacją ustroju państwowego, gdyż umożliwiłoby szerszym warstwom społeczeństwa dostęp do stanowisk sędziowskich i prokuratorskich ${ }^{30}$.

Postulat ten spotkał się ze sprzeciwem ministra sprawiedliwości - Henryka Świątkowskiego. Propozycje prezesa Najwyższego Sądu Wojskowego określił mianem „merytorycznie nieuzasadnionych”, gdyż zgodnie z art. $46 \$ 2$ Prawa o ustroju Sądów Wojskowych i Prokuratury Wojskowej z 23 października 1944 roku $^{31}$ przed oficerami służby sprawiedliwości nie są stawiane ,inne wymogi niż

\footnotetext{
${ }^{28}$ AAN MS 4301, k. 21.

${ }^{29}$ Jest to odręczna notatka, pod którą znajduje się nieczytelny podpis. AAN MS 4301, k. 24.

${ }^{30}$ Pismo z 16 X 1945 r. AAN MS 4301, k. 31.

${ }^{31}$ Dz.U. Nr 6, poz. 29.
} 
bliżej nieokreślone wykształcenie prawnicze (art. $46 \$ 2$ )”32. Zbędny byłby zapis uprawniający ministra obrony narodowej do udzielania zwolnień od wymagań ukończenia uniwersyteckich studiów prawniczych czy odbywania aplikacji sądowej i złożenia egzaminu sędziowskiego, ponieważ obowiązujące przepisy nie przewidują tego typu wymagań od osób zajmujących stanowiska sędziowskie, prokuratorskie i asesorskie w Wojsku Polskim. Swoje pismo zakończył uwagą, że jeżeli w opracowywanym przez ministra obrony narodowej prawie o ustroju sądów wojskowych i prokuratury wojskowej wprowadzone zostaną powyższe wymogi, to wówczas można będzie czynić wyjątki od tych wymogów.

Mocno zmodyfikowany projekt dekretu o wyjątkowym dopuszczeniu do obejmowania stanowisk sędziowskich, prokuratorskich i notarialnych oraz do wpisania na listę adwokatów został przedstawiony Radzie Ministrów. Zmiany, jakie przedstawiono Radzie Ministrów, sprowadzały się do uniezależnienia wpisu na listę adwokatów od ukończenia studiów prawniczych z przepisanymi w Polsce egzaminami (art. 3 ust. 1), przedłużenia okresu w jakim minister sprawiedliwości może udzielać przewidzianych w dekrecie zwolnień i zezwoleń $\mathrm{z}$ trzech do pięciu lat od dnia wejścia w życie dekretu (art. 4), oraz do wykreślenia $\mathrm{z}$ art. 1 ust. 1 słów „nabytą bądź przez pracę zawodową, bądź w uznanych przez Ministra Sprawiedliwości szkołach prawniczych" ${ }^{33}$.

Po wykreśleniu tych słów treść ustępu była następująca: Osoby, które ze względu na kwalifikacje osobiste oraz działalność naukową, zawodową, społeczną lub polityczną i dostateczną znajomość prawa dają rękojmię należytego wykonywania obowiązków sędziowskich lub prokuratorskich, mogą być mianowane na stanowiska asesora sądowego, sędziego lub prokuratora po udzieleniu im zwolnienia od wymagań ukończenia uniwersyteckich studiów prawniczych z przepisanymi w Polsce egzaminami, odbycia aplikacji sądowej i złożenia egzaminu sędziowskiego oraz przesłużenia określonej liczby lat na stanowiskach sędziowskich i prokuratorskich.

W uzasadnieniu projektu Ministerstwo Sprawiedliwości przychylnie odniosło się do propozycji przedłużenia $\mathrm{z}$ trzech do pięciu lat okresu, w którym minister sprawiedliwości udziela przewidzianych w dekrecie zwolnień i zezwoleń. Sprzeciwiło się natomiast wykreśleniu z art. 1 ust. 1 wymogu, by „dostateczna znajomość prawa" osób, które ubiegają się o nadzwyczajne nominacje na sędziów i prokuratorów, nie była nabyta w pracy zawodowej lub w uznanych przez ministra sprawiedliwości szkołach prawniczych. Według Ministerstwa Sprawiedliwości wymóg nabycia dostatecznej znajomości prawa w pracy zawodowej lub w uznanych przez ministra sprawiedliwości szkołach prawniczych zagwarantuje obiektywną ocenę wiedzy kandydata. Ministerstwo Sprawiedliwości krytycznie odniosło się także do pozostałych propozycji.

\footnotetext{
${ }^{32}$ Pismo U.Dz. 1941/45 z 30 X 1945 r. AAN MS 4301, k. 32.

${ }^{33}$ AAN MS 4301, k. 36.
} 
W przypadku uzależnienia wpisu na listę adwokatów od obowiązku ukończenia studiów prawniczych z przepisanymi w Polsce egzaminami Ministerstwo Sprawiedliwości uznało, że w zasadzie nie jest celowe dopuszczenie do zawodu adwokata osób nie posiadających studiów prawniczych, gdyż mogłoby to ujemnie odbić się na zawodowym i etycznym poziomie adwokatury. Jednocześnie Ministerstwo Sprawiedliwości przychylnie ustosunkowało się do zawartej w ustępie 2 artykułu 3 propozycji, by obrońcy sądowi i obrońcy przy sądach grodzkich, upoważnieni do prowadzenia spraw cudzych na mocy dekretu z 8 lutego 1919 roku w przedmiocie przepisów tymczasowych o obrońcach sądowych i obrońcach przy sądach pokoju mogli być wpisani na listę adwokatów, chociażby nie ukończyli studiów prawniczych z przepisanymi w Polsce egzaminami. Zdaniem Ministerstwa Sprawiedliwości, za wpisaniem obrońców sądowych i obrońców przy sądach grodzkich na listę adwokatów przemawiał fakt, że wszyscy oni posiadali długoletni staż pracy.

Dekret o wyjątkowym dopuszczeniu do obejmowania stanowisk sędziowskich, prokuratorskich i notarialnych oraz do wpisania na listę adwokatów został uchwalony przez Radę Ministrów 11 października 1945 r. ${ }^{34} \mathrm{~W}$ dekrecie uwzględniono wszystkie uwagi Ministerstwa Sprawiedliwości, łącznie z tą, by wpis na listę adwokatów uzależniony był od ukończenia studiów prawniczych z przepisanymi w Polsce egzaminami.

Warunkiem wejścia w życie dekretu, oprócz uchwalenia przez Radę Ministrów, było zatwierdzenie przez Prezydium Krajowej Rady Narodowej ${ }^{35}$. 28 kwietnia 1946 r. Krajowa Rada Narodowa dyskutowała nad projektem dekretu. Posłem sprawozdawcą Komisji Prawniczej był poseł Michał Szuldenfrei. Przedstawiając projekt dekretu podkreślał, że w wyniku działań wojennych sądownictwo polskie poniosło straty sięgające $45 \%$ przedwojennego stanu osobowego, jednocześnie wzrosła liczba spraw rozpatrywanych przez sądy, zwłaszcza spraw karnych i spraw niespornych (np. dotyczących uznania za zmarłego). Niezbędne zatem stało się przyjęcie dekretu, dzięki któremu szybko będzie można uzupełnić braki kadrowe w sądownictwie, prokuraturze, notariacie i adwokaturze. M. Szuldenfrei argumentował, że dekret o wyjątkowym dopuszczeniu do obejmowania stanowisk sędziowskich, prokuratorskich i notarialnych oraz do wpisania na listę adwokatów nie doprowadzi do obniżenia poziomu stanowisk i zawodów prawniczych, gdyż gwarancją należytej staranności stosowania dekretu jest upoważnienie jedynie ministra sprawiedliwości do warunkowego dopuszczania do zawodów prawniczych i to tylko przez okres pięciu lat. Wyraził

${ }^{34}$ Pismo Prezydium Rady Ministrów nr 112-13/2 z 31 XII 1945 r., z którego wynika, że 11 X 1945 roku dekret został uchwalony na posiedzeniu Rady Ministrów. AAN MS 4301, k. 39.

${ }^{35}$ Zgodnie z przepisami ustawy z 15 sierpnia 1944 r. o tymczasowym trybie wydawania dekretów z mocą ustawy (Dz.U. Nr 1, poz. 2) oraz ustawy z 3 stycznia 1945 r. o trybie wydawania dekretów z mocą ustawy (Dz.U. Nr 1, poz. 1), dekrety uchwalane przez Radę Ministrów musiały zostać zatwierdzone przez najbliższe plenarne posiedzenie Krajowej Rady Narodowej. 
przy tym nadzieję, że w tym okresie zostanie wykształcona odpowiednio duża liczba nowych prawników, którymi można będzie wypełnić powstałe luki. Zdaniem M. Szuldenfreia, za słusznością dekretu przemawiają również argumenty natury społecznej, mianowicie „obecna magistratura sądowa i prokuratorska przyjęła niemal w całości przedwojenny zespół sił sędziowskich i prokuratorskich, które przed wojną były często narzędziem klasowego wymiaru sprawiedliwości” ${ }^{36}$. Przepisy dekretu umożliwią przejście do sądownictwa i prokuratury robotniczego elementu, który zdobywając wiedzę na skróconych kursach w szkołach prawniczych, przyczyni się „do zmiany społecznego nastawienia przy wykonywaniu wymiaru sprawiedliwości” ${ }^{37}$.

Wniosek mniejszości Komisji Prawniczej przedstawił poseł Jan Sajdak. Zaznaczył, że w Komisji Prawniczej dekret przeszedł większością tylko jednego głosu. Podniósł, że dekret daje ministrowi sprawiedliwości możliwość powoływania na stanowisko sędziego oraz prokuratora każdego, kogo wcześniej zwolni od obowiązku ukończenia studiów prawniczych, aplikacji i zdania egzaminu sędziowskiego. Minister sprawiedliwości nie jest skrępowany wykształceniem kandydata, gdyż dekret milczy o tym czy kandydaci na sędziów i prokuratorów powinni posiadać wykształcenie średnie, czy może wystarczy tylko wykształcenie niższe. Zwrócił uwagę, że zawarte $\mathrm{w}$ dekrecie zastrzeżenie, iż kandydat powinien znać prawo, jest bezwartościowe, gdyż w dekrecie nie przewidziano, by kandydat musiał składać egzamin sędziowski. Całkowite zwolnienie $\mathrm{z}$ obowiązku składania egzaminu sędziowskiego wzbudza zaś uzasadnione obawy, że nastąpi obniżenie fachowych umiejętności oraz poziomu moralnego sędziów.

Poseł J. Sajdak zauważył również, że podnoszony przez posła sprawozdawcę katastrofalny brak sędziów i prokuratorów jest po części wynikiem bardzo niskiego uposażenia sędziów, które jest dużo niższe od zarobków zarówno rzemieślnika, jak i robotnika. Jeśli rzeczywiście brakuje 2000 sędziów i prokuratorów, to nie trzeba tworzyć przepisów wyjątkowych, jest sposób dużo prostszy, wystarczy 2000 aplikantów sądowych skrócić aplikację i dopuścić ich do egzaminu sędziowskiego.

Odnosząc się do argumentu dotyczącego dopływu świeżej krwi do skostniałego wymiaru sprawiedliwości, J. Sajdak zauważył, że świeża krew dopływa w sposób naturalny, gdy dzieci z rodzin robotniczych i chłopskich kończą studia i obejmują należne im stanowiska. Źle by się stało, gdyby został uchwalony dekret o wyjątkowym dopuszczeniu do obejmowania stanowisk sędziowskich, prokuratorskich i notarialnych oraz do wpisania na listę adwokatów. Po jego uchwaleniu jedno dziecko robotnicze lub chłopskie zostałoby sędzią po 14 latach przygotowania i zdaniu egzaminu sędziowskiego, drugiemu natomiast wystar-

${ }^{36}$ Sprawozdanie stenograficzne z posiedzeń Krajowej Rady Narodowej w dn. 26, 27 i 28 kwietnia 1946 r., Warszawa 1946, s. 428.

${ }^{37}$ Ibidem, s. 429. 
czyłoby tylko ukończenie wyjątkowego 6-miesięcznego kursu. W dalszej części argumentował, że gdyby dekret został uchwalony, to okazałoby się, że „inżynier musi być inżynierem, lekarz - lekarzem, tylko sędzią może być każdy bez przygotowania fachowego. Chyba nie dlatego, że decyduje o życiu i wolności oraz o czci obywateli” ${ }^{38}$. Na koniec dodał, że zło trzeba karać, a dobro wynagradzać, dlatego osoby zasłużone zawodowo, społecznie lub politycznie (art. 1 dekretu) powinny zostać wynagrodzone, ale nigdy stanowiskiem sędziego. Przecież obecny ustrój nie po to zniósł przywileje, by w miejsce usuniętych wprowadzać nowe uprzywilejowane grupy.

Następnie głos zabrał wiceminister sprawiedliwości Leon Chajn. Stwierdził, że znaczna cześć sędziów i prokuratorów wykazuje bierną postawę wobec przemian zachodzących w kraju, należy zatem wpompować do aparatu wymiaru sprawiedliwości świeżą krew. „Wejście do sądownictwa elementu robotniczego i chłopskiego spowoduje aktywną postawę polskiego wymiaru sprawiedliwości" ${ }^{39}$, będzie gwarancją praworządności.

Przekonując do uchwalenia dekretu, przytoczył wypowiedź kandydata do 6-miesięcznej szkoły prawniczej, robotnika, który ukończył 4 klasy szkoły powszechnej. Kandydat ów, odpowiadając dlaczego chce zostać prokuratorem, stwierdził, że ma usposobienie bojowca i chciałby poświęcić się „walce z byłymi ciemiężycielami, pragnącymi wydrzeć klasie pracującej owoce ich zwycięstw" ${ }^{\prime 40}$. Według L. Chajna wypowiedź ta dowodzi, że robotnicy i chłopi mogą pracować w sądach i prokuraturach, przyczyniając się do demokratyzacji sądownictwa. Po burzliwej dyskusji dekret został zatwierdzony.

W pierwszych latach Polski Ludowej nowa władza była zmuszona korzystać z przedwojennych, „burżuazyjnych” pracowników wymiaru sprawiedliwości. Była to dla niej sytuacja wysoce niedogodna, gdyż „starzy” pracownicy nie byli dyspozycyjni i nie dawali gwarancji wyrokowania zgodnie z wolą partii.

Dekret z 22 stycznia 1946 r. o wyjątkowym dopuszczeniu do obejmowania stanowisk sędziowskich, prokuratorskich i notarialnych oraz do wpisania na listę adwokatów dopuścił do zawodów prawniczych, zwłaszcza do sądownictwa i prokuratury osoby dyspozycyjne, uległe nowej władzy. Jednocześnie był on swoistą karą wymierzoną przedwojennym sędziom i prokuratorom za ich bierność i brak dyspozycyjności.

Uderzające jest, że twórcy dekretu wymagali większych kwalifikacji od kandydatów na adwokatów (obowiązek ukończenia studiów prawniczych i zdania przepisanych prawem egzaminów - art. 3 ust. 1), niż od kandydatów do pozostałych wymienionych $\mathrm{w}$ dekrecie stanowisk prawniczych. Wymowne jest również,

\footnotetext{
${ }^{38}$ Ibidem, s. 431 i 432

${ }^{39}$ Ibidem, s. 433 i 434

${ }^{40}$ Ibidem, s. 435.
} 
przytoczone już, zdanie krytyczne zawarte w opinii Ministerstwa Sprawiedliwości, a dotyczące obowiązku ukończenia uniwersyteckich studiów prawniczych i zdania przepisanych prawem egzaminów. Według Ministerstwa Sprawiedliwości, zlikwidowanie tego obowiązku mogłoby odbić się ujemnie „na zawodowym i etycznym poziomie adwokatury" ${ }^{41}$. Niestety, brak uniwersyteckiego wykształcenia w zakresie prawa nie budził tego typu obaw w przypadku innych zawodów prawniczych. 